\title{
Perspective
}

PERSPECTIVE Actualité en histoire de l'art

Comptes rendus | 2011

\section{Louis Henri Sullivan, Autobiographie d'une idée, Paris, Allia, 2011}

\section{Rémi Labrusse}

\section{(2) OpenEdition \\ Journals}

Édition électronique

URL : http://journals.openedition.org/perspective/2681

DOI : $10.4000 /$ perspective. 2681

ISSN : 2269-7721

Éditeur

Institut national d'histoire de l'art

Référence électronique

Rémi Labrusse, «Louis Henri Sullivan, Autobiographie d'une idée, Paris, Allia, 2011 », Perspective [En ligne], Comptes rendus, mis en ligne le 02 août 2013, consulté le 01 octobre 2020. URL : http:// journals.openedition.org/perspective/2681; DOI : https://doi.org/10.4000/perspective.2681

Ce document a été généré automatiquement le 1 octobre 2020. 


\section{Louis Henri Sullivan, Autobiographie d'une idée, Paris, Allia, 2011}

\section{Rémi Labrusse}

\section{RÉFÉRENCE}

Louis Henri Sullivan, Autobiographie d'une idée, Paris, Allia, 2011. 
Ce n'est pas pour y puiser un travail d'érudition historique qu'il faut acheter et lire cette première traduction française de l'œuvre autobiographique du plus singulier et du plus magistral des architectes de l'École de Chicago, Louis Henri Sullivan (1856-1924) : l'éditeur n'a pas souhaité en faire une édition savante, mais mettre en avant, strictement, la puissance littéraire d'un texte étrange et pénétrant, où l'histoire du fonctionnalisme architectural américain s'efface derrière un récit intime des origines, Bildungsroman à tonalités puritaines et prophétiques. Cette geste, parue pour la première fois en 1923 dans les livraisons estivales du Journal of the American Institute of Architects, rivalise avec les grands textes fondateurs de la littérature américaine, dans la lignée de

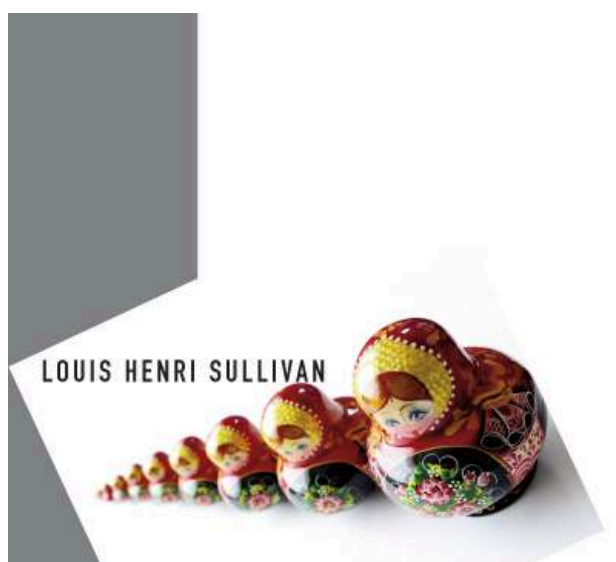

AUTOBIOGRAPHIE D'UNE IDÉE Henry David Thoreau et Nathaniel Hawthorne. Ses résonances bibliques, sa poétique de la nature révèlent en Sullivan, près de mourir, un des grands écrivains de son temps autant qu'un architecte et un inventeur presque fou de formes ornementales, auteur au même moment du non moins étrange System of Architectural Ornament (1924). La traduction de Christophe Gillouët rend avec un rare bonheur l'élan poétique de ce texte où le fonctionnalisme américain s'enracine dans une métaphysique rêveuse. 